\title{
Human Synaptonemal Complex Protein 1 (SCP1): Isolation and Characterization of the CDNA and Chromosomal Localization of the Gene
}

\author{
R. L. J. Meuwissen,* I. Meerts,* J. M. N. Hoovers, † N. J. Leschot,† and C. Heyting*,1 \\ *Department of Genetics, Agricultural University, Wageningen, The Netherlands; and † Institute of Human Genetics, \\ Academic M edical Center Amsterdam, Amsterdam, The Netherlands
}

Received April 30, 1996; accepted August 19, 1996

\begin{abstract}
Synaptonemal complexes (SCs) are structures that are formed between homologous chromosomes (homologs) during mei otic prophase. They consist of two proteinaceous axes, one along each homolog, that are connected along their length by numerous transverse filaments (TFS). The cDNA encoding one major component of TFs of SCs of the rat, rnSCP1, has recently been isolated and characterized. In this paper we describe the isolation and characterization of the cDNA encoding the human protein homologous to rnSCP 1, hSSCP1. hsSCP 1 and rnSCP1 have $75 \%$ amino acid identity. The most prominent structural features and amino acid sequence motifs of rnSCP1 have been conserved in hsSCP1. Most probably, hsSCP1 is functionally homologous to rnSCP1. The hSSCP1 gene was assigned to human chromosome 1p12-p13 by fluorescence in situ hybridization.
\end{abstract}

\section{INTRODUCTION}

The life cycle of sexually reproducing organisms is characterized by the alternation of diploid and haploid generations of cells. The transition from the diploid to the haploid state is accomplished at meiosis, which in mammals immediately precedes gametogenesis. At meiosis, a single round of DNA replication is followed by two successive nuclear divisions, meiosis I and II. During the prophase of meiosis I, homologous chromosomes (homologs) condense, pair, recombine, and disjoin. At meiosis II, the chromatids of each chromosome segregate, as in a mitotic division. The chromatin rearrangements of meiotic prophase are accompanied by the assembly and disassembly of synaptonemal complexes (SCs) ${ }^{2}$ (reviewed by von Wettstein et al., 1984).

\footnotetext{
${ }^{1}$ To whom correspondence should be addressed at Department of Genetics, Agricultural University, Dreyenlaan 2, NL-6703 HA Wageningen, The Netherlands. Telephone: +31-317-482150. Fax: +31317-483146. E-mail: Christa.Heyting@MolCelGen.EL.WAU.NL.

${ }^{2}$ Abbreviations used: $C E$, central element; TF, transverse filament; LE, lateral element; SC, synaptonemal complex; mmSCP1, mouse SCP 1; hamsynla, hamster SCP 1; rnSCP 1, rat SCP 1; hsSCP1, human SCP1; SSC, standard saline citrate (150 mM NaCl, $15 \mathrm{mM}$ sodium citrate, pH 7.0); PBS, phosphate-buffered saline (150 mM $\mathrm{NaCl}, 50 \mathrm{mM} \mathrm{Na} \mathrm{HPO}_{4} / \mathrm{NaH}_{2} \mathrm{PO}_{4}, \mathrm{pH}$ 7.4).
}

SCs consist of two proteinaceous axial cores or lateral elements (LEs), one along each homolog, that are connected along their length by numerous transverse filaments (TFS); a third longitudinal structure, the central element (CE), exists on the TFs, between both LES (Gillies, 1975; Schmekel et al., 1993).

To analyze the function of SCs, we have started to study their composition. Several protein components of SCs of rodents (Heyting et al., 1987, 1989; Smith and Benavente, 1992; Chen et al., 1992) and yeast (reviewed in Roeder, 1995) have been identified. Among these components were the putative TF proteins Ziplp of yeast (Sym et al., 1993; Sym and Roeder, 1995) and synaptonemal complex protein 1 (SCP1) of the rat (in this paper referred to as rnSCP1) (Meuwissen et al., 1992). The CDNA encoding rnSCP1 was isolated and sequenced (Meuwissen et al., 1992), and the predicted amino acid sequence was analyzed: rnSCP 1 consists of an $\alpha$-helical stretch of 700 amino acid residues, flanked by $\mathrm{N}$ - and $\mathrm{C}$-terminal globular domains. rnSCP 1 molecules are highly organized within SCs: the C-terminal domains are located in the inner half of the LEs, whereas the N-terminal domains lie in the vicinity of the CE (Schmekel et al., 1996). The C-terminal domain of rnSCP1 contains S/T-P (Ser/Thr-Pro) motifs, which are characteristic of DNA-binding proteins (Suzuki, 1989a; Churchill and Travers, 1991). The DNA-binding capacity of the C-terminal domain was recently demonstrated (Meuwissen et al., unpublished experiments). The gene encoding rnSCP1 is transcribed exclusively in meiotic prophase cells (Meuwissen et al., 1992). If, as seems likely, rnSCP1 is functionally homologous to Ziplp of yeast (Sym et al., 1993; Sym and Roeder, 1995), it probably has a function in the regulation of reciprocal crossing over and chromosome segregation (Sym and Roeder, 1994).

We cloned and characterized the cDNA encoding the human homolog of rnSCP1 (hSSCP1) to identify conserved domains within the protein and obtain a better insight into the importance of structural features and amino acid sequence motifs in SCP1. The predicted amino acid sequence of hsSCP1 has $75 \%$ identity to 
rnSCP 1 ; all prominent predicted structural features and most amino acid sequence motifs were conserved in hsSCP1. The gene encoding hsSCP1 was localized on human chromosome 1p12-p13 by fluorescence in situ hybridization (FISH). No human meiotic phenotype could becorrelated with abnormalities in the chromosome 1p12- p13 region.

\section{MATERIALS AND METHODS}

I solation of CDNAs encoding human SCP1. A human testis CDNA library in $\lambda$ gtl1 (Huynh et al., 1985) was screened with a polyclonal anti-rnSCP1 antiserum (Meuwissen et al., 1992) and the monoclonal anti-rnSCP1 antibody IX5B2 (Offenberg et al., 1991). Screening of 4 $\times 10^{5}$ phage yielded two positive clones with inserts of 1.5 and 1.8 $\mathrm{kb}$, respectively. A $5^{\prime}$ end probe of $350 \mathrm{bp}$ derived from the 1.8-kb insert was used for screening a human testis CDNA library in $\lambda$ gt10 (Huynh et al., 1985) (Clontech Laboratories Inc., Palo Alto, CA). This yiel ded a clone with a 2.7-kb insert that overlapped with the CDNAs from the $\lambda$ gt11 library. We obtained the missing 5 ' end of the human CDNA from the $\lambda$ gt10 library by means of PCR, for which we used two nested oligonucleotides homologous to the 2.7-kb cDNA insert and one oligonucleotide homologous to the $\lambda$ gt10 vector as primers: about $2 \times 10^{8}$ plaque-forming units of the $\lambda$ gt10 library were resuspended in $75 \mu$ l deionized water and heated for $5 \mathrm{~min}$ at $70^{\circ} \mathrm{C}$. Subsequently, the sample was adjusted to $1.5 \mathrm{mM} \mathrm{MgCl}_{2}, 0.2 \mathrm{mM} \mathrm{dATP}$, dGTP, dCTP, and dTTP, and 50 pmol of each of both primers and 2.5 units Taq polymerase (Pharmacia Biotech Europe) were added. The sample was incubated according to the following schedule: 1 cycle of $5 \mathrm{~min}$ at $95^{\circ} \mathrm{C} ; 30$ cycles of $1 \mathrm{~min}$ at $95^{\circ} \mathrm{C}, 1 \mathrm{~min}$ at $52^{\circ} \mathrm{C}$, and $2 \mathrm{~min}$ at $72^{\circ} \mathrm{C}$; and $1 \mathrm{cycle}$ of $1 \mathrm{~min}$ at $95^{\circ} \mathrm{C}, 1 \mathrm{~min}$ at $52^{\circ} \mathrm{C}$, and 15 min at $72^{\circ} \mathrm{C}$. The PCR yielded a 750-bp fragment, which, after Southern blot analysis (Sambrook et al., 1989), hybridized with the $5^{\prime}$ end probe of rnSCP1 CDNA. The 750-bp fragment was gel purified and sequenced with the use of oligonucleotide primers derived from the $5^{\prime}$ end of the human $2.7-\mathrm{kb}$ insert sequence and the $\lambda \mathrm{gt} 10$ vector. The nucleotide sequence of the $2.7-\mathrm{kb}$ insert was determined as follows: we subcloned the 2.7-kb cDNA insert into the pBluescript SK (+) (Stratagene Inc., San Diego, CA) vector and generated unidirectional sets of deletions from both ends of the $2.7-\mathrm{kb}$ insert by partial digestion with exonuclease III and S1 nuclease, using an Erase-a-base kit (Promega, Madison, WI). We performed the sequencing reactions on the deletion clones and the PCR products, using the Taq DyeDeoxy Terminator Cycle Sequencing Kit (PerkinElmer Inc., Palo Alto, CA) and analyzed the nucleotide sequences on an ABI 373A automatic DNA sequencer (Applied Biosystems Inc., F oster City, CA). The nucleotide sequence of human SCP1 (hsSCP1) was assembled by means of the GCG sequence analysis software package (University of Wisconsin, Madison, WI). Sequence similarity searches of GenBank, EMBL, Swissprot, and PIR databases were carried out with several BLAST programs (Altschul et al., 1990), FASTA and tFASTA (Pearson, 1990). Prediction of secondary structure was performed by means of a program based on Chou-Fasman algorithms (Chou and Fasman, 1978). Amino acid sequence alignments were determined using the Pile-Up program from the GCG sequence analysis software package (University of Wisconsin, Madison, $\mathrm{WI}$ ).

Fluorescence in situ hybridization analysis. A 2700-bp fragment of the human SCP1 CDNA was labeled with biotin-11-dUTP, whereas a human subtel omeric repeat probe, D1Z2, specific for chromosome 1 (Buroker et al., 1987), was labeled with digoxigenin-11dUTP. Both labeling reactions were performed by nick-translation, and both probes were mixed together for hybridization with the metaphase chromosomes. The metaphases were accumulated in EBV transformed human lymphocytes by the thymidine synchronization method (Viegas-Péquignot, 1993) and spread onto slides as described previously (Dauwerse et al., 1992). In situ hybridization was performed as described by Dauwerse et al . (1992). Briefly, the procedure was as follows: the metaphase chromosomes on slides were aged overnight at $60^{\circ} \mathrm{C}$. After this, they were incubated for $1 \mathrm{~h}$ at $37^{\circ} \mathrm{C}$ in
$100 \mu \mathrm{g} / \mathrm{ml}$ RNase in $2 \times \mathrm{SSC}$, washed for $3 \times 2 \mathrm{~min}$ in $2 \times \mathrm{SSC}$ at $37^{\circ} \mathrm{C}$, incubated for $10 \mathrm{~min}$ in $0.01 \%$ pepsin in $10 \mathrm{mM} \mathrm{HCl}$ at $37^{\circ} \mathrm{C}$, washed for $2 \times 5 \mathrm{~min}$ with PBS at room temperature, fixed for 10 min in $3.7 \%$ formaldehyde in PBS, washed for $2 \times 5 \mathrm{~min}$ in PBS, dehydrated successively in 70, 96, and 100\% ethanol (2 min per step), and air-dried. The chromosomes were then denatured for $5 \mathrm{~min}$ at $80^{\circ} \mathrm{C}$ in $60 \%$ formamide, $2 \times \mathrm{SSC}, 50 \mathrm{mM} \mathrm{NaH} \mathrm{PO}_{4} / \mathrm{Na}_{2} \mathrm{HPO}_{4}, \mathrm{pH}$ 7.0 , dehydrated, and fixed by incubation for $2 \times 5 \mathrm{~min}$ in $70 \%$ ethanol at $-20^{\circ} \mathrm{C}$, for $5 \mathrm{~min}$ in $96 \%$ ethanol at room temperature, and for 5 min in $100 \%$ ethanol at room temperature, and air-dried. The D1Z2 probe was dissolved in $50 \%$ formamide, $50 \mathrm{mM} \mathrm{Na} \mathrm{HPO}_{4} / \mathrm{NaH}_{2} \mathrm{PO}_{4}$, $\mathrm{pH}$ 7.0, 10\% dextran sulfate, and a 50-fold excess of Cot-1 DNA, denatured for $5 \mathrm{~min}$ at $70^{\circ} \mathrm{C}$, and prehybridized by incubation for 30 $\min$ at $37^{\circ} \mathrm{C}$. The hsSCP1 probe was dissolved in $50 \%$ formamide, $50 \mathrm{mM} \mathrm{Na} \mathrm{HPO}_{4} / \mathrm{NaH}_{2} \mathrm{PO}_{4}, \mathrm{pH} 7.0$, and $10 \%$ dextran sulfate, and denatured for $5 \mathrm{~min}$ at $70^{\circ} \mathrm{C}$ before it was mixed with the prehybridized D1Z2 probe. After mixing, the final concentration of D1Z2 was $5 \mathrm{ng} / \mu \mathrm{l}$, and the final concentration of hsSCP1 was $10 \mathrm{ng} / \mu \mathrm{l}$. The hybridization mixture was added to the pretreated slides for an overnight hybridization at $37^{\circ} \mathrm{C}$ in a moist chamber. After hybridization the slides were washed: for $3 \times 5 \mathrm{~min}$ at $42^{\circ} \mathrm{C}$ in $50 \%$ formamide, $2 \times$ SSC, pH 7.0; for $3 \times 5 \mathrm{~min}$ at $60^{\circ} \mathrm{C}$ in $0.1 \times$ SSC; and for $5 \mathrm{~min}$ at room temperature in $4 \times$ SSC, $0.05 \%$ Tween. Hybridized human SCP1 probe was detected by successive incubation rounds in avidinFITC conjugate and biotinylated goat anti-avidin antibodies. The hybridized subtelomeric repeat probe D1Z2 was detected by successive incubation rounds in mouse anti-digoxigenin, sheep anti-mouse antibodies, and anti-sheep IgG-TRITC conjugates. Counterstaining of the chromosomes was performed with DAPI in a Vectashield (Vecta Laboratories Inc.) antifade solution. Slides were examined in a Zeiss Axioplan epifluorescence microscope. For digital imaging microscopy the Cytovision Probe System (Applied I maging I nc., New Castle, UK) was used.

\section{RESULTS}

\section{I solation and Sequencing of Human SCP1 CDNAs}

A mixture of an affinity-purified polyclonal antirnSCP1 antiserum (Meuwissen et al., 1992) and a monoclonal anti-rnSCP1 antibody, IX5B2 (Offenberg et al., 1991), was used for screening $4 \times 10^{5}$ recombinant phage of a human testis $\lambda$ gt11 cDNA library. This yielded two clones with insert sizes of 1.5 and $1.8 \mathrm{~kb}$, respectively. Both cDNA inserts had overlapping restriction enzyme maps and displayed nucleotide sequence homology with the rat SCP1 CDNA sequence. We performed a secondary screening of a human testis $\lambda$ gt10 cDNA library to isolate the remaining part of the human cDNA (see Materials and Methods). Extensive screening of the independent $\lambda g t 10$ and $\lambda$ gt11 CDNA libraries yielded only a single type of cDNA clones, i.e., we found only one type of human CDNA clones homologous to the rat SCP 1 CDNA. The complete human SCP1 (hsSCP1) CDNA sequence contained an open reading frame of 2928 nucleotides, which encoded a protein of 976 amino acids (Fig. 1). The translation initiation codon in the human CDNA sequence (Fig. 1, nucleotide positions 95-97) was the first ATG in the open reading frame and is preceded by a consensus sequence for eukaryotic translation initiation (Kozak, 1986). Furthermore, in the amino acid sequence alignment of hsSCP1 and three rodent SCP1 proteins (Fig. 2), the first 6 amino acid residues are identical. 
GCCCTCATAGACCGTTTGTTGTAGTTCGCGTGGGAACAGCAACCCACGGTTTCCCGATAGTTCTTCAAAGATATTTACAACCGTAACAGAGAAA

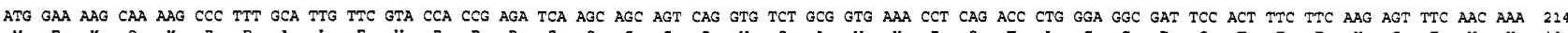

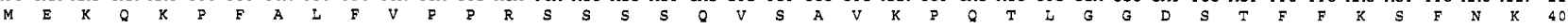

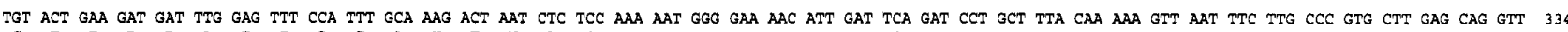

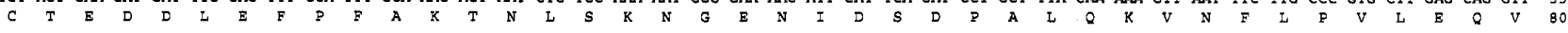

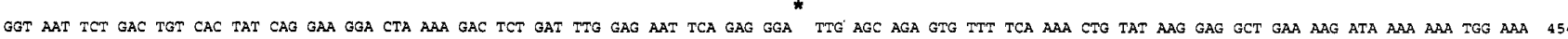

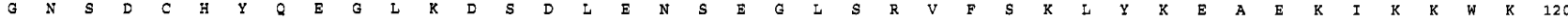

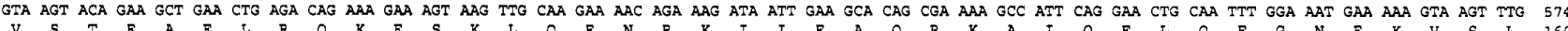

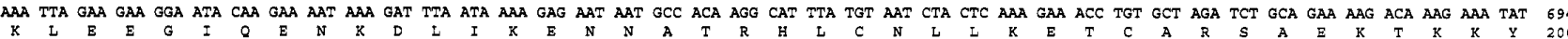

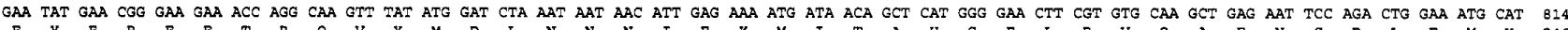

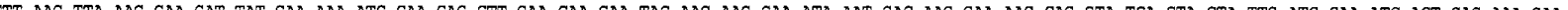

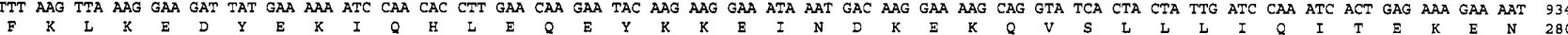

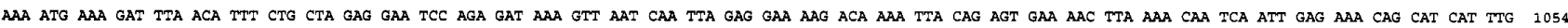

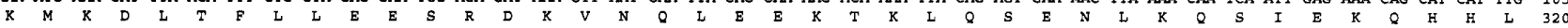

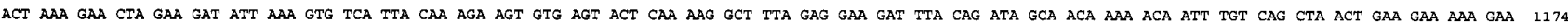

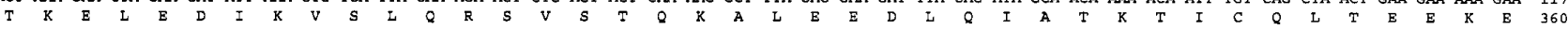

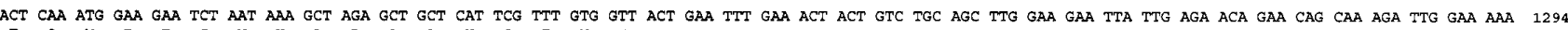

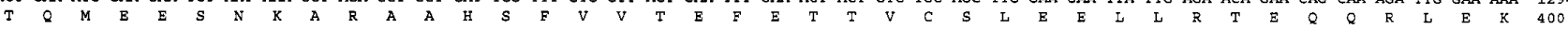

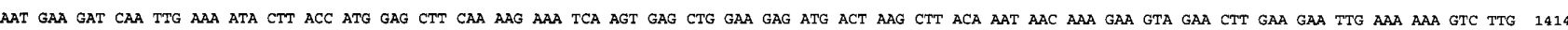

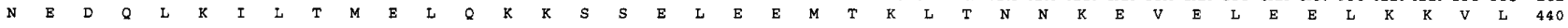

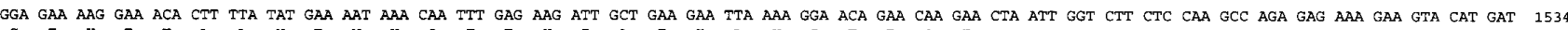

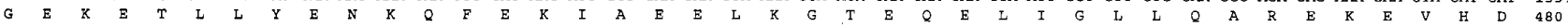

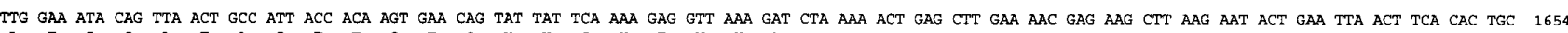

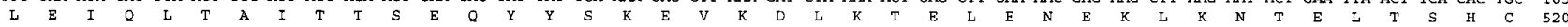

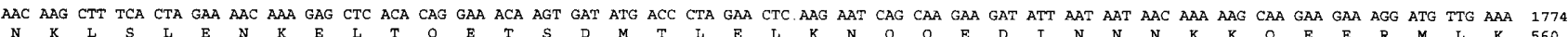

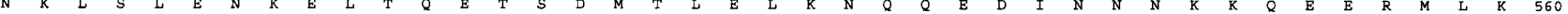

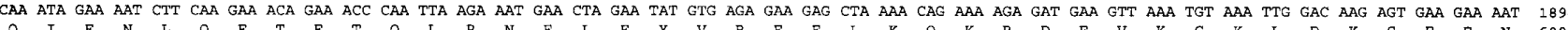

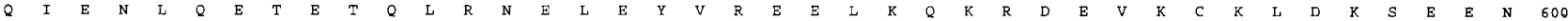

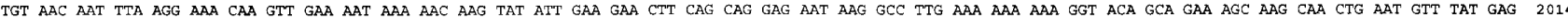

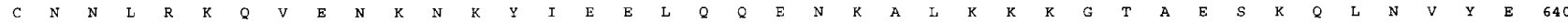

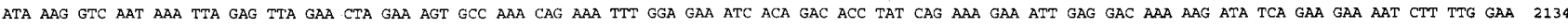

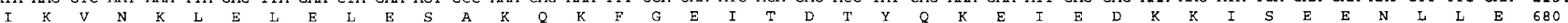

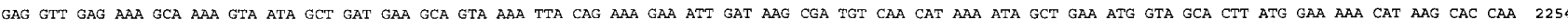

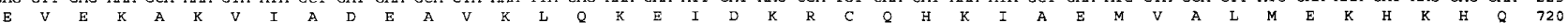

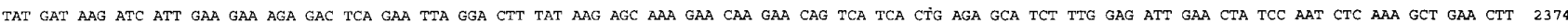

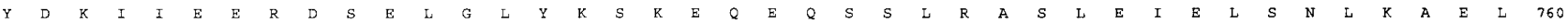

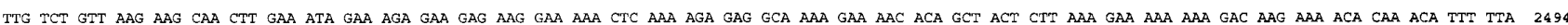

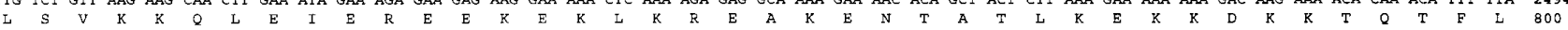

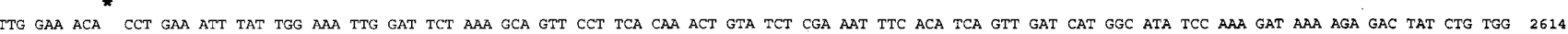

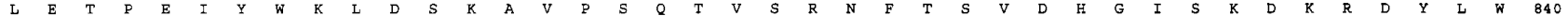

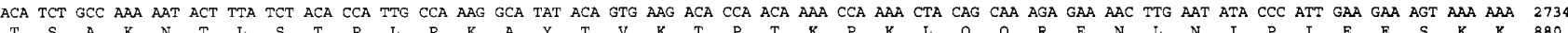

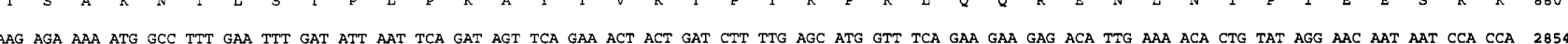

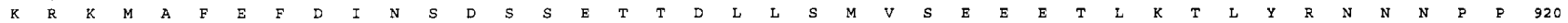

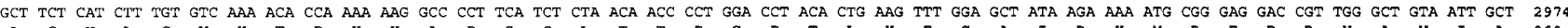

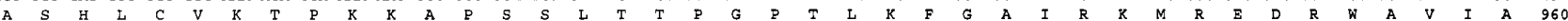
AAA ATG GAT AGA AAA AAA AAA CTA AAA GAA GCT GAA AAG TTA TTT GTT TAA

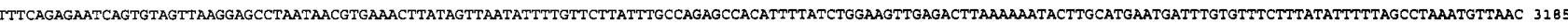

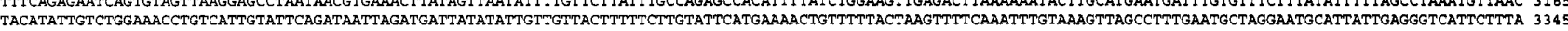
TACATATTGTCTGGAAACCTGTCATTGTATTCAGATAATTAGATGATTA

FIG. 1. Nucleotide sequence and derived amino acid sequence of the CDNA encoding hsSCP1. The predicted translation product is presented bel ow the first nucleotide of each codon. The putative poly(dA) addition signal and addition site are underlined. The ends of the coiled-coil region as predicted according to Lupas et al. (1991), with a window of 28 amino acids, are indicated by asterisks. The name and Accession No. for the human SCP1 CDNA sequence in the EMBL database are hsSCP1 and X95654, respectively.

\section{Amino Acid Sequence Homology between the Different SCP1 Proteins}

The amino acid identity between hSSCP1 and SCP1 of the mouse (Sage et al., 1995), hamster (Dobson et al., 1994), and rat (Meuwissen et al., 1992) is 74.6, 74.4, and $75.7 \%$, respectively. The amino acid identity is distributed evenly over hSSCP1, except for the C-terminal 174 amino acid residues, from hsSCP1 positions 802 to 976 , which show only $64.5 \%$ amino acid identity. However, the level of amino acid sequence identity in the hsSCP 1 alignment (Fig. 2) is sufficient to imply a structural and functional similarity between hSSCP1 and the rodent SCP1 proteins (Sander and Schneider, 1991).

\section{Amino Acid Sequence Features of SCP1}

The structural organization of the SCP1 proteins is very similar. Like the rodent SCP1s, hSSCP1 has three distinct domains, each having its own characteristic secondary structure as predicted by the algorithm of 
m m sp 1

rns cp 1

hamsyn 1 a

h s $\mathbf{c p} 1$

mms cp 1

rnscp 1

hamsyn1a

hs $\mathbf{s p} 1$.

mms cp 1

rnscp 1

hamsyn1a

hs $\mathbf{s p} 1$

mms cp 1

rnscp 1

hamsyn1a

hs cp 1

mms cp 1

rnscp 1

hamsyn1a

hs $\mathrm{sp} 1$

mmscp 1

rnscp 1

hamsyn 1 a

hs $\mathrm{sp} 1$

mms cp 1

rnscp 1

hamsyn 1 a

hs s cp 1

mms cp 1

rnscp 1

hamsyn 1 a

hs s cp 1

mms cp 1

rnscp 1

hamsyn 1 a

hs $\mathbf{c p} 1$

mms cp 1

rnscp 1

hamsyn 1 a

hs $\mathbf{s p} 1$

mms cp 1

rns cp 1

hamsyn 1 a

hs $\mathbf{s p} 1$

mms cp 1

rnscp 1

hamsyn1a

hs s cp 1

mms cp 1

rns cp 1

hamsyn 1 a

hs s cp 1

mms cp 1

rnscp 1

hamsynia

hs s cp 1

mms cp 1

rnscp 1

hamsyn1a

hs s cp 1

mm sp 1

rnscp 1

hamsyn 1 a

hs s cp 1

MERQKPFTLFVP PRLSSSQVSAVKPQTAGGDSNYFKTVNKCTEGDFGVPFTMSS . . . . RENIDKD MEKQK P TLFVPPRLSSSQVSAVKPQTAGGDSNYFKTVNKCTEGDF GVPLTMSSLSKNRENIDTD

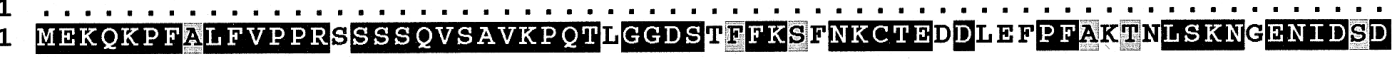

62 PAFQKLSILPMLEQVANSGSCHYQEGVNDSDFENSEPMSRLYSKLYKEAEKIKKWKVSIESELKQ 66 PAFQKLSILPMLEQVANSGSCHYQEGVNDSDFENSEPMSRLYSKLYKEAEKIKKWKVSIESELKQ

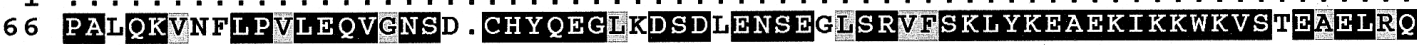

127

131

1

130

KENKLQFNRKIIEAQRKAI QELQFENEKVSLKL FEEI QENKDLIKENNATIHWCNLLKETCARSA KENKLQENRKIIEAQRKAI QEL QF ENEKVSLKLEEEIQENKDLIKENNATRHWCNLLKETCARSA

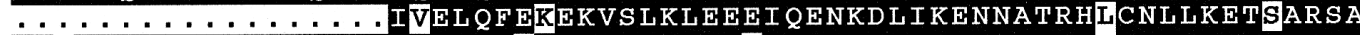

192 EKTNKYEYEREETRQVYVDLNSNI EKMI LAFEELRVQAENAR LEMH FKLKEDHEKI QHLEEEYQK 196 EKTSKYEYEREETRQVYVDLNNNIEKMILAFEELRVQAENARLEMH FKLKEDHEKIQHLEEEYQK 48 EKTNKYEYERETTRQVYVDLNNNI EKMI LAFEELRVQAENARLDMH F KLKEDHEKI QH LQEEYKK 195 EKTKKYEYEREETRQVYMDLNNNI EKMITAHGELRVQAENSRLEMH FKLKEDYEKI QHLEQEYKK

257 EVNNKENQVSELLIQSAEKENKMKDLT FLLEGSRDKANQLEEKTKLQDENLKELSEKKDHLTS FL 261 EVNNKENQVSLLLIQSTEKENKMKDLT FLLEESRDKANQLEEKTKLQDENLKELNEKKDHLTSEL 113 EVNDKENQVSLLLI QRTEKENKMKDLT FLLEESRDKVNQLEDKTKL QDENVKELNKKKDHLTS EL 260 FINDKEKQVSLLL I QITEKENKMKDL T LLEESRDKVNQLEEKTKL QSENLKQSIEKQHH LTKEL

322 EDIKMSMQRSMSTQKALEFDLQIATKTISQLTEVKEAQMEFLNKAKTTHSFVVT ELKATTCTLEF 326 ED I KMSMQRSMSTQKTLEEDLQIATKTIYQLTEEKEAQMEELNKAKTTHSLVVTELKATTCTLEE 178 EDTKMSLQRSMNT QKALEEDLQIATKTIYQLTEEKEAQMEEFNKAKTDHS FMVTELKATTCTLEE 325 EDIKVSLQRSVSTQKALEEDLQIATKTICQLTEEKETQMEESNKARAAHSF VVTEFETTVCSLEE

387 LLRTEQQRLEKNED QLKLITVELQKKSNELFEMTKF KNNKEVELEELKNI LAED QKLLDEKKQVE 391 LLRTEQQRLENNED QLKLITMELQKKSSELEEMTKFKNNKEVELEELKTI LAED QKLLDEKKQVE 243 LLRT EQQRLVKNED QLKI LTMEL QKKS NELDEMTKF KNNNEVKLEELKK I LAED QKLLDEKKQVE 390 LLRTEQQRLEKNED QLKI LTMELQKKSSELEEMTKLTNNKEVELEELKKVLGEKETLLYENKQFE

452 KLAFELQEKEQELTFLLETREKEVHDLQEQVTVTKTSEQHYLKQVEFMKTELEKEKLKNTELTAS 456 KLAEELQGKEQELTFLLQTREKETHDLEVQVTVTKTSEEHYLKQVEEMKTELEKEKLKNIELTAN 308 KLAEELQGKEQELTLLLQTREKEVHDLEEQLLVTKISDQNYSKQVEELKTKLEEEKLKNAELTAS 455 KIAEFLKGTEQELIGLLQAREKEVHDLEIQLTAITTSEOYYSKEVKDLKTELENEKLKNTELTSH

517 CDMLLLENKK FVEASDMALELKKHQED I ICKKQEERLLKQ I FNLEEKEMHLRDELESVRKEF I 521 SDMLLLENKKLVQEAS DMVLELKKHQEDI I NCKKQEERMLKQI ETLEEKEMNLRDELESVRKEFI 373 CGKLSL FNNKLTQETNDMALELKKYQEDITNSKKQEERMLKQI ENLEFKETHLRDELESVRKEFI 520 CNKLSLENKELTQETSDMTLELKNQQED INNNKKQEERMLKQI FNLQETETQLRNE LEYVREELK

582 QQGDEVKCKLDKS EFNARS I ECFVLKKEKQMKILESKCNNLKKQVFNKSKNIEELHQENKTLKKK 586 Q Q DEVKCKLDKSEENARS I EYFVLKKEKQMKI LENKCNNLKKQTENKSKNI E ELHQENKALKKK 438 QQNEVVKCLDKS EENARS I ECEVLKKEKQMKI LENKCNNLRK QAENKSKYIEELHQENKALKKK 585 QKRDEVKCKLDKSEEN . . . . . . . . . . . . CNNLRKQVENKNKYIEELQQENKALKKK

647 SSAEIKQLNAYEIKVSKLELELESTKQRFEEMTNNYQKEI ENKKIS FGKLLGEVEKAKATVDEAV 651 SSAENKQLNAYEIKVNKLELELASTKQKFEEMINNYQKEIEIKKISEEKLLGEVEKAKATVDEAV 503 SSAESKQLNAYEIKVNKLQLELESÄKQKF QEMTDNYQKEI EVKKISEEKLLGEVEKAKAMVDEAV 629 GTAESKQLNVYEI KVNKLELELESAKQKFGETTDTYQKEI EDKKI S EENLLEEVEKAKVIADEAV

712 KLOKEI DLRCOHKI AEMVALMEKHKHQYDKIVEERDSELGLYKNREQEQSSAKIALET ELSNIRN $716 \mathrm{KL} Q K$ EIDLRCQHKIAEMVALMEKHKHQYDKIVEERDSELGLYKNREQEQSSAKVALET ELSNIRN 568 KLOKEIDLRCQHKIAEMVALMEKHKHQYDKIVEERDSELGLCKNREQEQLSVKTALET ELSNIRN 694 KLQKEIDKRCQHKI AEMVALMEKHKHQYDKITEERDSELGLYKSKEQEQSSLRASLEIELSNLKA

777 ELVSLKKQLEIFKEFKEKLKMA . KENTAILKDKKDKKI QASLLESPEATSWKFDSKTTPSQNISR 781 ELVSLKKQLEVEKEEKEKLKME. QENTAILTDKKDKKI QASLLESPEATSWKFDSKTTPSQNISR 633 ELVSLKKQLEIFREFKEKLKLE. KENTAILKDKKDKKI QTSLLESAFTTCQKF DSKTTPSQNISR 759 ELLSVKKQLEIERERKEKLKREAKENTATLKEKKDKKTQTFLLFTPE. IYWKLDSKAVPSQTVSR

841 LSSSMDSGKSKDNRDNLRASAKS I LPTTVTKEYTVKT PTKKS IYQRENKYI PTGGS NKKRKTAFE 845 LSSSMDSGKSKDNRDSLRASAKS I LST TTKEYTVKTPTKKSIYQRENKYLPTGGSNKKRKTVFE 697 ISSSMESGKTKDNRDCLRTSAK. I LSTAFVKEYTVKTPTKMQMYQRENKYIPTGRSNKKRKTVFE 823 NFTSVDHGISKDKRDYLWTSAKNTLSTPLPKAYTVKT PTKPKLQQRENLNI PIEESKKKRKMAF E

906 FDVNSDSSETADLLSLVSEEDVSNRLY 761 FDVNSDSSETTDLLSMVSEEEI SNRLY. NNNSPNSHL. . . T PKQT PLSLSTPES FVSLGGVRKMR 888 FDTNSDSSETTDLLSMVSEEETLKTLYRNNNPPASH LCVKT PKKAPSS LTTPGPTLKFGAIRKMR 


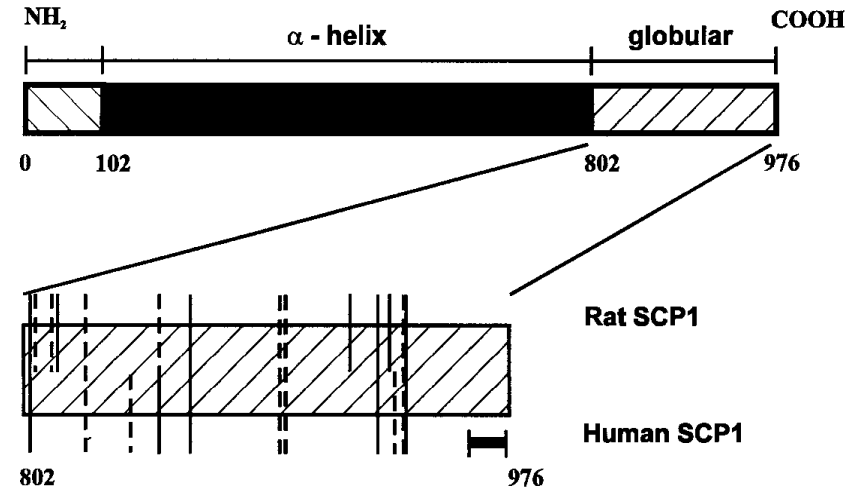

FIG. 3. Comparison of the localization of the $S / T-P$ motifs in SCP1 from rat and human. A diagrammatic presentation of SCP1 is shown. The sizes of the three different domains are indicated by the amino acid residue numbers for hSSCP1. An enlargement of the Cterminal end of SCP1 is shown, in which the S/T-P motifs are indicated by solid vertical bars and the $\mathrm{S} / \mathrm{T}-\mathrm{S} / \mathrm{T}$ motifs by broken vertical bars. The basic $\mathrm{C}$-terminal domain is indicated by a horizontal bar.

Chou and Fasman (1978). In hsSCP1, the N-terminal domain includes amino acid residues $1-102$. It is rich in acidic amino acids and does not contain any structural motifs. From position 102 to 802 , hsSCP1 has a predicted amphipatic $\alpha$-helical domain; within this domain hSSCP1 has a deletion of 21 amino acid residues compared to rodent SCP1s (Fig. 2). We found the corresponding deletion in three independently isolated CDNA clones, two of which originated from the human testis CDNA library in $\lambda$ gt11 and one from the CDNA library in $\lambda$ gt10. The deletion of 21 amino acids does not disturb the heptad repeat frame of the predicted amphipatic $\alpha$-helix. The C-terminal domain of hSSCP1 extends from positions 803 to 976 , is enriched in basic amino acids, and has a predicted pl of 9.8 , compared with a pl of 5.9 for the entire hsSCP1 protein. Another feature of the C-terminal domain of hsSCP 1 is the presence of $5 \mathrm{~S} / \mathrm{T}-\mathrm{P}$ and $7 \mathrm{~S} / \mathrm{T}-\mathrm{S} / \mathrm{T}$ motifs. The $\mathrm{S} / \mathrm{T}-\mathrm{P}$ motifs are common in various DNA-binding proteins (Suzuki, 1989a; Churchill and Travers, 1991) and are believed to contribute to DNA binding (Suzuki, 1989b; Green et al., 1993). S/T-S/T motifs can adopt a conformation similar to that of the S/T-P motif (Suzuki, 1989a). The localization of both motifs is shown in Fig. 3. Although the presence of $\mathrm{S} / \mathrm{T}-\mathrm{P}$ and $\mathrm{S} / \mathrm{T}-\mathrm{S} / \mathrm{T}$ motifs is conserved in SCP 1, their number and exact position are not. One $\mathrm{S} / \mathrm{T}-\mathrm{S} / \mathrm{T}$ motif of $\mathrm{rnSCP} 1$ has turned into an S/T-P motif in hsSCP1, namely on position 850 of hsSCP1 (Fig. 3).
Other amino acid sequence motifs that are conserved in the four SCP1 proteins analyzed in this paper and their amino acid positions in hSSCP1 are: two potential nuclear target sites at the positions 120-124 and 879883 (consensus $K-R / K-X-R / K$, where $X$ is any amino acid; Roberts, 1989); a p34 ${ }^{\text {cdc2 }}$ kinase target site at positions 928- 933 (Z-(S/T)-P-X-Z, where $X$ is polar and Z is generally basic; Langan et al., 1989); a leucine zipper motif (Landschulz et al., 1988) at positions 391-419; a tyrosine kinase target site at positions 728-735 (R/ K-X(2)-D/E-X(3)-Y, Cooper et al., 1984); three CAMP/ cGMP-dependent protein kinase target sites at positions 414-417, 627-630, and 671- 674 (R/K(2)-X-S/T, Glass et al., 1986), and 12 protein kinase $C$ target sites (S/T-X-R/K, Kishimoto et al., 1985) that are dispersed over the hSSCP1 protein. Thesmall basic domain at the C-terminus in all four SCP1 proteins (hsSCP1 positions 948-976) shows $29 \%$ amino acid sequence identity with the DNA-binding domain of a protein-tyrosine phosphatase of the rat (Radha et al., 1993). All SCP1 proteins show amino acid sequence similarity to several filamentous proteins like keratin or myosin, but this similarity does not exceed that expected on the basis of an amphipatic $\alpha$-helical structure. No sequence homology to other proteins was detected.

\section{Chromosomal Localization of the Human SCP1 Gene}

Two-col or fluorescence in situ hybridization was used to localize the human SCP1 gene to chromosome 1p12p13 (Fig. 4). A biotinylated CDNA probe for hsSCP1 was detected with FITC, and a subtelomeric repeat probe for the short arm of chromosome 1 (D1Z2) (Buroker et al., 1987) was labeled with digoxigenin and detected with TRITC. Analysis of 25 informative, DAPIbanded metaphases with two signals on both chromosomes 1 enabled us to localize SCP 1 to chromosome 1p12-p13.

\section{DISCUSSION}

In this paper we describe the isolation of the cDNA encoding the human protein (hSSCP1) homologous to synaptonemal complex protein 1 of the rat (rnSCP1). The overall amino acid sequence identity of hSSCP1 to rodent SCP1 is about $75 \%$. The three distinct domains that are found in rodent SCP Is also occur in hSSCP1. No domains can be discerned in SCP1 that are consid-

FIG. 2. Amino acid sequence alignment of the known rodent SCP1 proteins with the hsSCP1 protein. Alignments were performed by means of the PileUp program (GCG software package, University of Wisconsin, Madison, WI), and the results are presented using the Boxshade program (Bioinformatics Group, ISREC, Lausanne, Switzerland). Identical amino acids are highlighted in black; similar amino acids are highlighted in gray. The following amino acids were considered similar: $(M, V, I, L),(D, E, Q, N),(S, A, T, G)$, and $(H, R, K)$. Abbreviations: mmscp1, mouse SCP1 (Sage et al., 1995); rnscp1, rat SCP1 (Meuwissen et al., 1992); hamsyn1a, hamster SCP1 (Dobson et al., 1994); hsscp1, human SCP1. The complete amino acid sequence of the hamster SCP1 is not known (Dobson et al., 1994). The dots at the $\mathrm{N}$-terminal part of the hamster SCP 1 represent the unknown amino acid sequence. The remaining dots represent the gaps in the amino acid sequence alignment. The predicted amino acid sequence of rnSCP1 in this figure extends 51 amino acids further in the N-terminal direction than the originally published sequence (Meuwissen et al., 1992). Due to a sequencing error, the codon CCC for a proline residue was read as $\mathrm{CC}$. This resulted in a frameshift by which the first six amino acid residues of rnSCP1 were missed. Thereupon the start codon was erroneously located at amino acid position 52 of rnSCP1 (Sage et al., 1995; Meuwissen, unpublished results). 


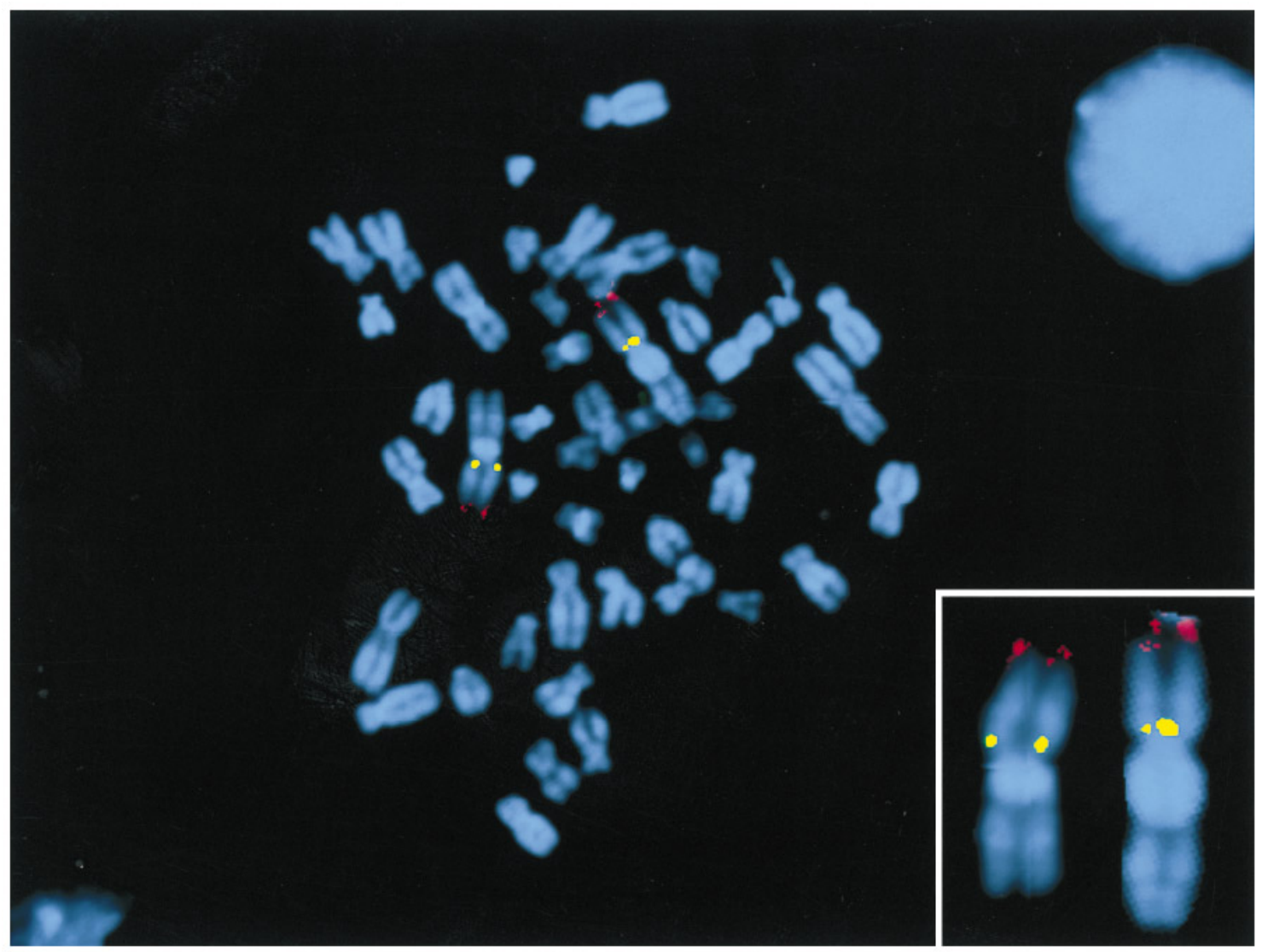

FIG. 4. Localization of the human SCP1 gene to chromosome 1p12-p13. Metaphase chromosomes from human Iymphocytes were hybridized with a mixture of two probes: a biotin-dUTP labeled probe derived from hsSCP1 CDNA (detected with FITC, yellow pseudocolor and a digoxigenin-dUTP labeled human subtelomeric repeat probe D1Z2 (detected with TRITC, red pseudo-color). The chromosomes were counterstained with DAPI (blue). We considered the presence of a paired signal as a positive localization. (Inset) Enlargement of the individual chromosomes \#1 of the same metaphase.

erably more strongly conserved than the protein as a whole. The C-terminal domain is somewhat less well conserved than the whole SCP 1 molecule: $64 \%$ versus $75 \%$ amino acid identity. Because no other human CDNAs encoding proteins homologous to rnSCP1 were found, despite extensive screening with anti-rnSCP1 antibodies and probes derived from the cDNA for rnSCP1, we believe that hSSCP1 is the human functional homolog of rnSCP1. This is further supported by the fact that various motifs have been conserved. With respect to the $\mathrm{S} / \mathrm{T}-\mathrm{P}$ and $\mathrm{S} / \mathrm{T}-\mathrm{S} / \mathrm{T}$ motifs, it appears as if the presence of these motifs in the C-terminal domain is important, but their exact position is not. hsSCP1 has five $\mathrm{S} / \mathrm{T}-\mathrm{P}$ and seven $\mathrm{S} / \mathrm{T}-\mathrm{S} / \mathrm{T}$ motifs, whereas rnSCP1 has seven S/T-P and seven $\mathrm{S} / \mathrm{T}-\mathrm{S} / \mathrm{T}$ motifs. Only nine of these motifs are at exactly corresponding positions. The S/T-P and S/T-S/T motifs are thought to cause $\beta$-turns in peptide chains so that these chains get a "kinky" conformation; such chains are thought to fit into the minor groove of DNA and to make contact with the phosphoribose backbone at the $\beta$-turns (Suzuki, 1989a; Churchill and Suzuki, 1989). The precise positions of the S/T-P and S/T-S/T motifs are not very crucial for that (Suzuki, 1989a). Some S/T-S/T motifs in rnSCP1 are S/T-P motifs in hsSCP1 (e.g., at position
850 in hsSCP1), which indicates that the presence of the $\beta$-turn is important. In vitro, the C-terminus of rnSCP1 binds to DNA (Meuwissen et al., unpublished experiments).

Another conserved amino acid sequence motif that deserves attention is the $p 34^{\text {cdc2 }}$ protein kinase target site. This site also occurs in nuclear lamins A and C, where it is involved in the regulation of the disassembly of the nuclear lamina at mitosis (Heald and McKeon, 1990). In budding yeast (Saccharomyces cerevisiae), mutations of CDC28, which is the gene equivalent to cdc2 of fission yeast (Schizosaccharomyces pombe), results in a block in the pachytene stage of meiosis: SCs are not disassembled in these mutants (Davidow and Byers, 1984; Shuster and Byers, 1989). Two other conserved potential phosphorylation sites are the CAMP/ cGMP dependent protein kinase (PKA) target sites. Inhibition of phosphorylation by PKA is important for the disassembly of the nuclear lamina at mitosis (Lamb, 1991). It will therefore be of interest to discover if the potential p34 cdc2 and PKA phosphorylation sites in SCP1 are phosphorylated in vivo.

Mutation of SCP1 will most probably result in defects in meiosis, such as chromosomal nondisjunction (Sym et al., 1993; Sym and Roeder, 1994) and infertility. As 
yet, no human phenotypes have been identified that are linked with defects in meiosis and that are correlated with chromosomal abnormalities in human chromosome 1p12-p13 (Weith et al., 1996). Further analysis of the human 1p12-p13 chromosomal area together with mutational analysis of SCP1 in rodents should provide more information about the meiotic function of SCP1.

\section{ACKNOWLEDGMENTS}

We thank M. van Aalderen and M. E. J acobs (Academical Medical Center Amsterdam) for expert technical assistance; L. Coolen and $B$. Ronda for performing part of the experiments in the course of their undergraduate study, and Dr.J . H. de J ong for discussions and practical advice. This research was supported by the Netherlands Organization for the advancement of Scientific Research.

\section{REFERENCES}

Altschul, S. F., Gish, W., Miller, W., Myers, E. W., and Lipman, D. J . (1990). Basic local alignment search tool. J . Mol. Biol. 215: 403410.

Buroker, N., Bestwick, R., Haight, G., Magenis, R. E., and Litt, M. (1987). A hypervariable repeated sequence on human chromosome 1p36. Hum. Genet. 77: 175- 181.

Chen, Q., Pearlman, R. E., and Moens, P. B. (1992). I solation and characterization of a cDNA encoding a synaptonemal complex protein. Biochem. Cell. Biol. 70: 1030-1038.

Chou, P. Y., and Fasman, G. D. (1978). Prediction of the secondary structure of proteins from their amino acid sequence. Adv. Enzymol. 47: 45- 148.

Churchill, M. E., and Suzuki, M. (1989). 'SPKK' motifs prefer to bind to DNA at A/T-rich sites. EMBO J . 8: 4189- 4195.

Churchill, M. E., and Travers, A. A. (1991). Protein motifs that recognize structural features of DNA. Trends Biochem. Sci. 16: 92-97.

Cooper, J . A., Esch, F. S., Taylor, S. S., and Hunter, T. (1984). Phosphorylation sites in enolase and lactate dehydrogenase utilized by tyrosine protein kinases in vivo and in vitro. J . Biol. Chem. 259: 7835- 7841.

Dauwerse, J . G., Wiegant, J ., Raap, A. K., Breuning, M. H., and van Ommen, G. J . (1992). Multiple col ors by fluorescence in situ hybridization using radio-labeled DNA probes create a molecular karyotype. Hum. Mol. Genet. 1: 593-598.

Davidow, L. S., and Byers, B. (1984). Enhanced gene conversion and postmeiotic segregation in pachytene-arrested Saccharomyces cerevisiae. Genetics 106: 165-183.

Dobson, M. J ., Pearlman, R. E., Karaiskakis, A., Spyropoulos, B., and Moens, P. B. (1994). Synaptonemal complex proteins: Occurrence, epitope mapping and chromosome disjunction. J. Cell Sci. 107: 2749-2760.

Gillies, C. B. (1975). An ultrastructural analysis of chromosomal pairing in maize. C. R. Trav. Lab. Carlsberg 40: 135- 161.

Glass, D. B., el-Maghrabi, M. R., and Pilkis, S. J . (1986). Synthetic peptides corresponding to the site phosphorylated in 6-phosphofructo-2-kinase/fructose-2,6-bisphosphatase as substrates of cyclic nucleotide-dependent protein kinases. J . Biol. Chem. 261: 29872993.

Green, G. R., Lee, H.J ., and Poccia, D. L. (1993). Phosphorylation weakens DNA binding by peptides containing multiple "SPKK" sequences. J . Biol. Chem. 268: 11247-11255.

Heald, R., and McKeon, F . (1990). Mutations of phosphorylation sites in lamin A that prevent nuclear lamina disassembly in mitosis. Cell 61: 579- 589.

Heyting, C., Moens, P. B., van Raamsdonk, W., Dietrich, A.J.J ., Vink, A. C. G., and Redeker, E. J . W. (1987). Identification of two major components of the lateral elements of synaptonemal complexes of the rat. Eur. J . Cell Biol. 43: 148- 154.

Heyting, C., Dietrich, A. J .J ., Moens, P. B., Dettmers, R. J ., Offenberg, H. H., Redeker, E. J . W., and Vink, A. C. G. (1989). Synaptonemal complex proteins. Genome 31: 81-87.

Huynh, T. V., Young, R. A., and Davis, R. W. (1985). Constructing and screening cDNA libraries in $\lambda$ gt10 and $\lambda g t 11$. In "DNA Cloning: A Practical Approach" (D. M. Glover, Ed.), Vol. I, pp. 49-78, IRL Press at Oxford Univ. Press, Oxford.

Kishimoto, A., Nishiyama, K., Nakanishi, H., Uratsuji, Y., Nomura, H., Takeyama, Y., and Nishizuka, Y. (1985). Studies on the phosphorylation of myelin basic protein by protein kinase $C$ and adenosine 3':5'-monophosphate-dependent protein kinase. J. Biol. Chem. 260: 12492- 12499.

Kozak, M. (1986). Point mutations define a sequence flanking the AUG initiator codon that modulates translation by eukaryotic ribosomes. Cell 44: 283- 292.

Lamb, N. J ., Cavadore, J . C., Labbe, J . C., Maurer, R. A., and Fernandez, A. (1991). Inhibition of CAMP-dependent protein kinase plays a key role in the induction of mitosis and nuclear envelope breakdown in mammalian cells. EMBO J . 10: 1523- 1533.

Landschulz, W. H., J ohnson, P. F., and McKnight, S. L. (1988). The leucine zipper: A hypothetical structure common to a new class of DNA binding proteins. Science 240: 1759- 1764.

Langan, T. A., Gautier, J ., Lohka, M., Hollingsworth, R., Moreno, S., Nurse, P., Maller, J., and Sclafani, R. A. (1989). Mammalian growth-associated $\mathrm{H} 1$ histone kinase: $\mathrm{A}$ homolog of $\mathrm{cdc} 2+/ \mathrm{CDC} 28$ protein kinases controlling mitotic entry in yeast and frog cells. Mol. Cell. Biol. 9: 3860-3868.

Lupas, A., Van Dyke, M., and Stock, J . (1991). Predicting coiled coils from protein sequences. Science 252: 1162- 1164.

Meuwissen, R. L.J ., Offenberg, H. H., Dietrich, A. J .J ., Riesewijk, A., van Iersel, M., and Heyting, C. (1992). A coiled-coil related protein specific for synapsed regions of meiotic prophase chromosomes. EMBO J . 11: 5091-5100.

Offenberg, H. H., Dietrich, A.J .J ., and Heyting, C. (1991). Tissue distribution of two major components of synaptonemal complexes of the rat. Chromosoma 101: 83-91.

Pearson, W. R. (1990). Rapid and sensitive sequence comparison with FASTP and FASTA. Methods Enzymol. 183: 63-98.

Radha, V., Kamatkar, S., and Swarup, G. (1993). Binding of a protein-tyrosine phosphatase to DNA through its carboxy-terminal noncatalytic domain. Biochemistry 32: 2194- 2201.

Roberts, B. (1989). Nuclear location signal-mediated protein transport. Biochim. Biophys. Acta 1008: 263- 280.

Roeder, G. S. (1995). Sex and the single cell: Meiosis in yeast. Proc. Natl. Acad. Sci. USA 92: 10450- 10456.

Sage, J ., Martin, L., Cuzin, F., and Rassoulzadegan, M. (1995). cDNA sequence of the murine synaptonemal complex protein 1 (SCP1). Biochim. Biophys. Acta 1263: 258-260.

Sambrook, J., Fritsch, E. F., and Maniatis, T. (1989). "Molecular Cloning: A Laboratory Manual," pp. 9.31-9.57, Cold Spring Harbor Laboratory Press, Cold Spring Harbor, NY.

Sander, C., and Schneider, R. (1991). Database of homology-derived protein structures and the structural meaning of sequence alignment. Proteins 9: 56-68.

Schmekel, K., Skoglund, U., and Daneholt, B. (1993). The threedimensional structure of the central region in a synaptonemal complex: A comparison between rat and two insect species, Drosophila melanogaster and Blaps cribrosa. Chromosoma 102: 682- 692.

Schmekel, K., Meuwissen, R. L.J ., Dietrich, A. J . J ., Vink, A. C. G., van Marle, J., van Veen, H., and Heyting, C. (1996). Organization of SCP1 protein molecules within synaptonemal complexes of the rat. Exp. Cell Res. 226: 20-30.

Shuster, E. O., and Byers, B. (1989). Pachytene arrest and other meiotic effects of the start mutations in Saccharomyces cerevisiae. Genetics 123: 29-43.

Smith, A., and Benavente, R. (1992). Meiosis-specific protein selec- 
tively associated with sex chromosomes of rat pachytene spermatocytes. Proc. Natl. Acad. Sci. USA 89: 6938-6942.

Suzuki, M. (1989a). SPXX, a frequent sequence motif in gene regulatory proteins. J . Mol. Biol. 207: 61-84.

Suzuki, M. (1989b). SPKK, a new nucleic acid-binding unit of protein found in histone. EMBO J . 8: 797-804.

Sym, M., and Roeder, G. S. (1994). Crossover interference is abolished in the absence of a synaptonemal complex protein. Cell 79: 283-292.

Sym, M., and Roeder, G. S. (1995). Zipl-induced changes in synaptonemal complex structure and polycomplex assembly. J . Cell Biol. 128: 455- 466.

Sym, M., Engebrecht, J . A., and Roeder, G. S. (1993). ZI P1 is a synap- tonemal complex protein required for meiotic chromosome synapsis. Cell 72: 365- 378.

Viegas-Péquignot, E. (1993). In situ hybridization to chromosomes with biotinylated probes. In "In situ hybridization: a practical approach" (D. G. Wilkinson, Ed.), pp. 139-141, IRL Press at Oxford Univ. Press, New York.

von Wettstein, D., Rasmussen, S. W., and Holm, P. B. (1984). The synaptonemal complex in genetic segregation. Annu. Rev. Genet. 18: $331-413$.

Weith, A., Brodeur, G., Bruns, G., Matise, T., Mischke, D., Nizetic, D., Seldin, M., van Roy, N., Vance, J . (1996). Report of the second international workshop on human chromosome 1 mapping 1995. Cytogenet. Cell Genet. 72: 113- 154. 